\title{
AN ATTEMPT OF APPLY THE WEIBULL DISTRIBUTION IN ROAD TRAFFIC LOSSES ANALYSIS
}

\section{PRÓBA ZASTOSOWANIA ROZKLADU WEIBULLA DO ANALIZ STRAT W RUCHU DROGOWYM}

\author{
Anita Milewska ${ }^{1}$, Joanna Żukowska ${ }^{2}$ \\ (1) Gdansk University of Technology, Faculty of Applied Physics and Mathematics \\ Politechnika Gdańska, Wydzial Fizyki Technicznej i Matematyki Stosowanej \\ 80-952 Gdańsk ul. Narutowicza 11 \\ (2) Gdansk University of Technology, Faculty of Civil \\ and Environmental Engineering \\ Politechnika Gdańska, Wydział Inżynierii Lądowej i Środowiska \\ 80-952 Gdańsk ul. Narutowicza 11 \\ e-mails: (1)amilewska@mif.pg.gda.pl, (2)joanna.zukowska@wilis.pg.gda.pl
}

\begin{abstract}
The paper presents an attempt of applying the Weibull distribution for the purpose of analysing road traffic losses (fatalities). The question it asks is whether reliability engineering methods can be applied for the analyses. If this is the case, what should be the interpretation of the numbers and terms? It was assumed that the losses generated by a malfunctioning road transport system are fatalities. Risk exposure to these losses is defined with the average number of vehicles using the roads.
\end{abstract}

Key words: road safety, fatalities, Weibull distribution, reliability

Streszczenie: W referacie przedstawiono próbę zastosowania rozkładu Weibulla do analiz strat (ofiar śmiertelnych) w ruchu drogowym. Postawiono w nim pytanie: czy mogą być one analizowane metodami niezawodności technicznej? A jeżeli tak, to jaka jest interpretacja poszczególnych wielkości i pojęć? Przyjęto, że straty wynikające $\mathrm{z}$ nieprawidłowego funkcjonowania systemu transportu drogowego to śmiertelne ofiary wypadków drogowych. Ekspozycja na ryzyko pojawienia się tych strat jest natomiast określana średnią liczbą pojazdów, jaka rzeczywiście bierze udział w ruchu drogowym.

Słowa kluczowe: ruch drogowy, bezpieczeństwo, śmiertelne ofiary wypadków drogowych, rozkład Weibulla, niezawodność 


\section{TESTING THE WEIBULL DISTRIBUTION IN ROAD TRAFFIC LOSSES ANALYSIS}

\section{Introduction}

The world today depends on efficient transport systems for development. This includes road safety. Scientific studies are key to understanding this problem [2]. Research is equally important for carrying out broader analyses to identify global trends, compare the figures from different countries, study the effectiveness of the measures and forecast the developments in the years to come. Studies of road safety problems primarily use the following methods [4]:

- statistical studies (models of road safety measures distribution, models of road safety indicators, "before and after" analyses, factor analyses, regression analyses, etc.),

- behavioural studies (roadside observations, in-vehicle observations, laboratory tests, conflict observations, interviews and surveys, etc.),

- tests using models including physical models, simulation and analytical models.

This paper presents an example of applying the Weibull distribution and how it can be used to analyse road traffic losses (fatalities). The question it asks is whether reliability engineering methods can be used to analyse transport losses? And if this is the case, what should be the interpretation of the numbers and terms? In our approach it was assumed that the loss generated by a malfunctioning road transport system is road deaths. The exposure to the risk of generating these losses is defined with the average number of vehicles that actually use the roads.

\section{Chapter 2}

\subsection{Weibull's Distribution}

Let us consider a family of functions of this form:

$$
F(t)=\left\{\begin{array}{cc}
1-\exp \left(-\frac{t^{\delta}}{\theta}\right) & \text { dla } t>0 \\
0 & \text { dla } t \leq 0
\end{array},\right.
$$


where $\delta, \theta$ are any real and positive numbers. For the set parameters $\delta, \theta$ function $F(t)$ is the cumulative distribution function of random variable $T$, which we say has a Weibull distribution $[1,3]$. Because of the infinite number of times we can choose the values $\delta, \theta$ we can test whether the property $T$ has a cumulative distribution function with a distribution function which belongs the distribution function class $F(t ; \delta, \theta)$, where unknown parameters $\delta, \theta$ are determined using a sample.

It is sufficient to consider the cumulative distribution function of a random variable $T$ with a Weibull distribution for $t>0$ only, i.e. $F(t)=1-\exp \left(-\frac{t^{\delta}}{\theta}\right)$. We transform $[1]$ :

$x=\ln t, \quad y=\ln \ln \frac{1}{1-F(t)}$,

and represent the distribution's distribution function as a line:

$y=\delta x-\ln \theta$.

The coefficients of this line can be determined using the method of least squares using the empirical distribution function $F_{E}(t)$ for $t=t_{i}$, $i=1, \ldots, n$, where $n$ means the size of the sample. This also determines parameters $\delta, \theta$ of the Weibull distribution.

\subsection{Determining the parameters $\delta, \theta$ using a sample}

We are going to analyse monthly road crash fatality numbers collected from 1 January 1990 to 31 December 2006. We will include annual figures of passenger cars between $1999-2001$ and $2003-2006$, which show that the average number of passenger cars was $A=11245675$.

Let random variable $T$ denote time (number of months from 1 January 1990) of road deaths records. The question is whether random variable $T$ has a Weibull distribution? The available data are used to determine the empirical distribution function $F_{E}(t)$, which is that for $t \leq 0$ we have $F_{E}(t)=0$ and for $t=t_{i}$, where $i=1, \ldots, 204$ (204 is the number of months from 1 January 1990 to 31 December 2006), we have $F_{E}\left(t_{i}\right)=\frac{B_{i}}{\gamma \cdot A}$, where $B_{i}$ means the cumulative number of fatalities from the start of month 1 until the end of month $i$, and $\gamma$ is the positive coefficient. 
For the purpose of the analysis we agreed that road traffic is used monthly by $70 \%$ of the average number of passenger cars. The model can also be applied if the coefficient $\gamma=0,7$ is replaced with e.g. $\gamma=0,6$ or $\gamma=0,8$ or $\gamma=1$ etc. But the objective of this paper is not to determine the optimal value of the coefficient, but to test whether feature $T$, which is significant for road safety has a Weibull distribution.

Points $\left(t_{i}, F_{E}\left(t_{i}\right)\right), i=1, \ldots, 204$, correspond in the transformation (2) to points $\left(x_{i}, y_{i}\right)$, which are approximately on a line (see Fig. 1$)$. That way we have carried out an initial verification of the proposition that the property has a Weibull distribution. Using the method of least squares we establish that the line has the equation $y=1,00378 \cdot x-9,54681$. For the sample under analysis points $\left(x_{i}, y_{i}\right), i=1, \ldots, 204$ and the line are presented in Fig.1.

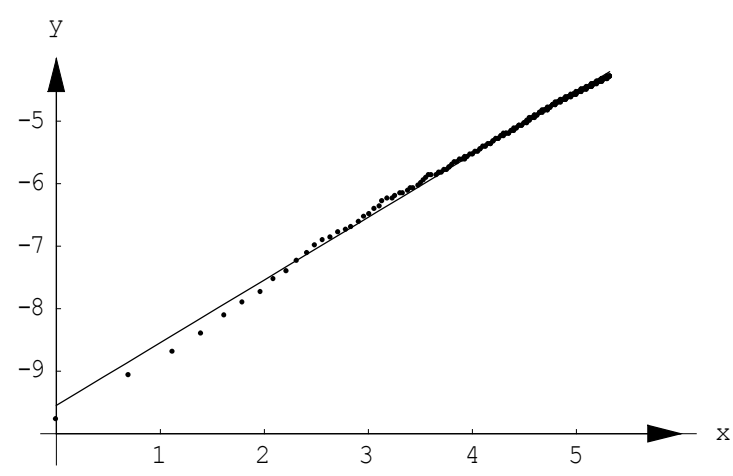

Fig.1. Points $\left(x_{i}, y_{i}\right)$ and straight line $y=1,00378 \cdot x-9,54681$

According to formula (3) we get with some approximation:

$\delta=1,00378, \quad \theta=\exp (9,54681)=13999,96348$.

The above values are substituted to formula (1) and we get function $F(t)$, which we call the theoretical (hypothetical) distribution function. There are only minor differences between the values $F_{E}\left(t_{i}\right)$ of the empirical distribution function and values $F\left(t_{i}\right)$ of the theoretical distribution. The graphs of both distribution functions for $t=1, \ldots, 204$ are given in Fig. 2 (darker colour is the theoretical distribution function). 


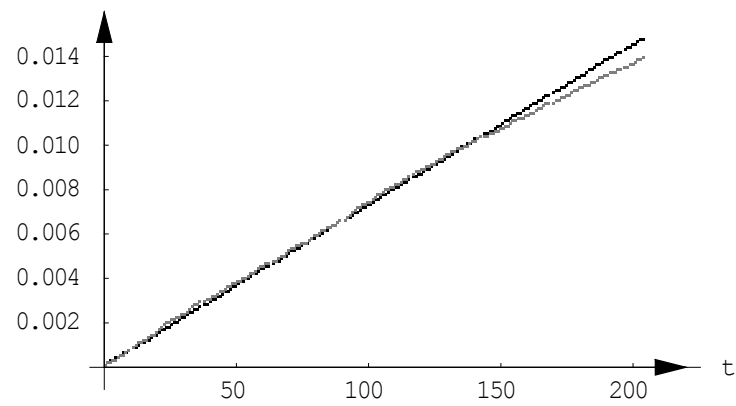

Fig.2. Graphs of functions $F(t), F_{E}(t)$ for $t=1, \ldots, 204$

\subsection{Verifying the Weibull's distribution hypothesis}

We make the hypothesis that random variable $T$ has a Weibull distribution with parameters $\delta, \theta$. The values of these parameters are estimated using the sample. They are given in formula (4). We will verify the hypothesis using the Kolmogorov test [5] at significance level of $\alpha=0,05$. The test statistics is $D=\sup \left|F\left(t_{i}\right)-F_{E}\left(t_{i}\right)\right|$. For significance level of $\alpha=0,05$ the critical value of Kolmogorov statistics is $d_{(0,05)}=1,354$. If $\sqrt{204} \cdot D<d_{(0,05)}$, then the sample does not contradict the hypothesis at significance level of $\alpha$, otherwise the hypothesis will be rejected for the significance level adopted. Following the calculations we get $\sqrt{204} \cdot D \approx 0,0124804<d_{(0,05)}$, so the sample under analysis at significance level of $\alpha=0,05$ does not contradict the hypothesis that the feature $T$ has a Weibull distribution.

\section{Chapter 3}

\subsection{Analysing the properties of a feature with Weibull's distribution}

The parameters $\delta, \theta$ given in formula (4) were estimated on the basis of the sample. They can be used to analyse certain functions $[1,3]$, e.g. the density function $f(t)$, intensity function $\lambda(t)$, reliability function $R(t)$. These functions for a Weibull distribution are determined for $t>0$ with the following formulas:

$$
f(t)=\frac{\delta}{\theta} \cdot t^{\delta-1} \cdot \exp \left(-\frac{t^{\delta}}{\theta}\right), \quad \lambda(t)=\frac{\delta}{\theta} \cdot t^{\delta-1}, \quad R(t)=\exp \left(-\frac{t^{\delta}}{\theta}\right),
$$


and for $t \leq 0$ we have $f(t)=0, \lambda(t)=0, R(t)=1$. Graphs of the function $\lambda(t), R(t)$ are given in Fig.3.
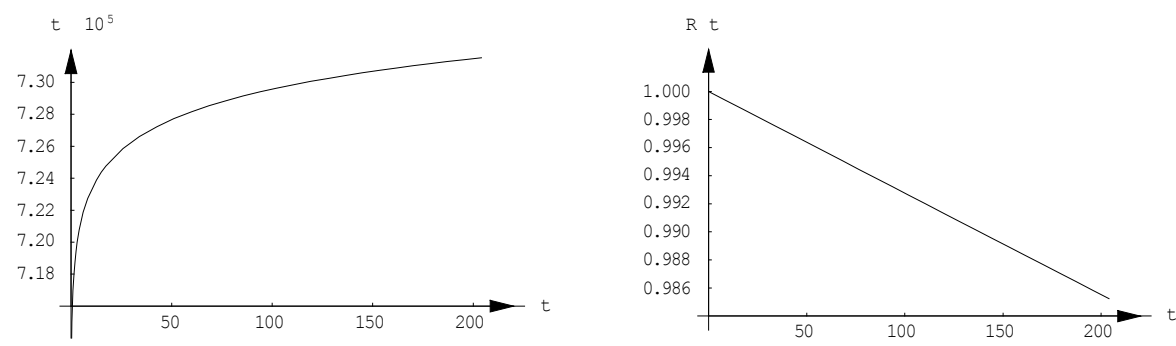

Fig.3. Graphs of functions $\lambda(t), R(t)$

\subsection{Interpreting the results of the analysis}

The system operates in a failure mode. Losses occur in the system (in our case they are fatalities). Random variable $T$ means the operation time with a failure, $F(t)$ is the probability of fatalities occurring until moment $t$, while $R(t)$ means the probability that fatalities will occur after moment $t$. Function $R(t)$ is decreasing, which in our case means that the probability of a fatality after moment $t$ decreases. This is the type of situation, which the National Road Safety Programme GAMBIT 2005 expects.

The dynamics of the decrease in system failure reliability is defined by intensity function $\lambda(t)$. We can accept that function $\lambda(t)$ is in this case the intensity function of lack of loss. For estimated parameters $\delta, \theta$ the function is increasing, which means that lack of losses increases which in turn means that losses are in decline (more road users do not die in road accidents). This is the desirable situation. But the question remains: is the dynamics of the decline satisfactory?

\section{Conclusions}

Random variable $T$ has a Weibull distribution for different values of $\gamma$. The method hypothetically can use other methods for modelling risk exposure in a road transport system, for example by using information about the number of kilometres travelled (vehicle kilometres), number of vehicles (not just passenger cars) or the size of the population.

Methods based on the reliability theory can be used for analysing losses generated in road transport, but the values will be interpreted individually. 
It was established that the global road safety trend measured with the number of road deaths is positive, i.e. declining. However, there is reason to believe that the dynamics of the fatality reduction is too small to reach the target set out in the National Road Safety Programme GAMBIT 2005 of not more than 2800 fatalities in 2013.

The method offers new opportunities for road transport safety analysis. It enables comparisons between different countries, the progress made in reaching targets and how it was achieved and the links between traffic risk and level of exposure. This method can also be used for forecasts and simulations.

\section{References}

1. Bobrowski D.: Wprowadzenie matematyczne do teorii niezawodności. Wyd. PP, Poznań, 1977.

2. Hakamies-Blomqvist L.: Ageing Europe: The Chalanges and Opportunities for Transport Safety. ETSC. www.etsc.be, 2003.

3. Koźniewska I., Włodarczyk M.: Modele odnowy, niezawodności $i$ masowej obstugi. PWN, Warszawa, 1978.

4. OECD: Road safety principles and models. Road Transport Research. OECD Publication. Paris, 1996.

5. Plucińska A., Pluciński E.: Rachunek prawdopodobieństwa. Statystyka matematyczna. Procesy stochastyczne. WN-T, Warszawa 2006. 


\section{PRÓBA ZASTOSOWANIA ROZKLADU WEIBULLA DO ANALIZ STRAT W RUCHU DROGOWYM}

\section{Wstęp}

Rozwój współczesnego świata w zdecydowanym stopniu zależy od sprawności funkcjonowania systemu transportowego, w tym od bezpieczeństwa ruchu drogowego. Badania naukowe mają fundamentalne znaczenie dla poznania istoty tego zjawiska [2]. Są także niezbędne na poziomie analiz znacznie szerszych, wyjaśniających globalne trendy, porównujących sytuacje $\mathrm{w}$ różnych krajach, skuteczność podejmowanych działań, prognozujących rozwój sytuacji w nadchodzących latach.

Podstawowymi metodami badań stosowanymi w odniesieniu do problemów bezpieczeństwa ruchu drogowego (brd) są [4]:

- badania statystyczne (modele rozkładów miar brd, modele trendów wskaźników brd, analizy „przed i po”, analizy czynnikowe, analizy regresyjne itp.),

- badania behawioralne (obserwacje na drodze, obserwacje w pojeździe, testy laboratoryjne, obserwacje sytuacji konfliktowych, wywiady i badania ankietowe itp.),

- badania na modelach z uwzględnieniem modeli fizycznych, modeli symulacyjnych oraz modeli analitycznych.

W niniejszym referacie przedstawiona została próba zastosowania rozkładu Weibulla do analiz strat (ofiar śmiertelnych) w ruchu drogowym. Postawiono w nim pytanie: czy wielkość strat $\mathrm{w}$ transporcie drogowym może być analizowana metodami niezawodności technicznej? A jeżeli tak, to jaka jest interpretacja poszczególnych wielkości i pojęć?

W zaprezentowanym podejściu przyjęto, że straty wynikające $\mathrm{z}$ nieprawidłowego funkcjonowania systemu transportu drogowego to śmiertelne ofiary wypadków drogowych. Wprowadzono założenie, że ekspozycja na ryzyko pojawienia się tych strat jest określana średnią liczbą pojazdów osobowych, jaka bierze udział w ruchu drogowym. 


\section{Rozdzial 2}

\subsection{Rozktad Weibulla}

Rozważmy rodzinę funkcji postaci:

$$
F(t)=\left\{\begin{array}{cc}
1-\exp \left(-\frac{t^{\delta}}{\theta}\right) & \text { dla } t>0 \\
0 & \text { dla } t \leq 0
\end{array},\right.
$$

gdzie $\delta, \theta$ sa dowolnymi liczbami rzeczywistymi dodatnimi. Dla ustalonych parametrów $\delta, \theta$ funkcja $F(t)$ jest dystrybuantą pewnej zmiennej losowej $T$, o której mówimy, że ma rozkład Weibulla [1,3]. Ze względu na nieskończoną ilość możliwości wyboru wartości $\delta, \theta$ możemy zbadać, czy rozważana cecha $T$ ma rozkład o dystrybuancie należącej do klasy dystrybuant $F(t ; \delta, \theta)$, gdzie nieznane parametry $\delta, \theta$ wyznacza się wówczas na podstawie próby.

Wystarczy rozważyć dystrybuantę zmiennej losowej $T$ o rozkładzie Weibulla tylko dla $t>0$, czyli $F(t)=1-\exp \left(-\frac{t^{\delta}}{\theta}\right)$. Wprowadzając przekształcenie [1]:

$x=\ln t, \quad y=\ln \ln \frac{1}{1-F(t)}$,

odwzorowujemy dystrybuantę rozkładu w prostą:

$y=\delta x-\ln \theta$.

Współczynniki tej prostej można wyznaczyć metodą najmniejszych kwadratów z wykorzystaniem dystrybuanty empirycznej $F_{E}(t)$ dla $t=t_{i}$, $i=1, \ldots, n$, gdzie $n$ oznacza liczność próby. Tym samym wyznaczone zostaną parametry $\delta, \theta$ rozkładu Weibulla.

\subsection{Wyznaczanie parametrów $\delta, \theta$ na podstawie próby}

Poddamy analizie dane miesięczne o ilości ofiar śmiertelnych w wypadkach drogowych, zebrane od 1 stycznia 1990 r. do 31 grudnia 2006 r. Uwzględnimy ponadto dane roczne o ilości pojazdów osobowych w latach 1999 - 2001 i 2003 - 2006, z których wynika, że średnia ilość pojazdów osobowych wynosiła $A=11245675$. 
Niech zmienna losowa $T$ oznacza czas (liczony w miesiącach począwszy od 1 stycznia 1990r.) rejestrowania ofiar śmiertelnych w wypadkach drogowych. Nasuwa się pytanie, czy zmienna losowa $T$ ma rozkład Weibulla? Na podstawie posiadanych danych wyznaczamy dystrybuantę empiryczną $F_{E}(t)$, taką że dla $t \leq 0$ mamy $F_{E}(t)=0$ oraz dla $t=t_{i}$, $i=1, \ldots, 204$, mamy $F_{E}\left(t_{i}\right)=\frac{B_{i}}{\gamma \cdot A}$, gdzie $B_{i}$ oznacza skumulowaną ilość ofiar śmiertelnych od początku miesiąca $\mathrm{nr} 1$ do końca miesiąca $\mathrm{nr} i$, natomiast $\gamma$ jest dodatnim współczynnikiem. W analizie przyjęliśmy założenie, że w ruchu drogowym uczestniczy miesięcznie $70 \%$ średniej ilości pojazdów osobowych, tzn. przyjęliśmy $\gamma=0,7$.

Uwaga. Jak sprawdzono, przedstawiony model ma zastosowanie również wtedy, gdy zamiast współczynnika $\gamma=0,7$ przyjmiemy np. $\gamma=0,6$ lub $\gamma=0,8$ lub $\gamma=1$ itp. Jednak celem tej pracy nie jest dyskusja nad optymalną wartością tego współczynnika, lecz sprawdzenie m. in., czy cecha $T$ istotna z punktu widzenia brd ma rozkład Weibulla przy różnych $\gamma$.

Punktom $\left(t_{i}, F_{E}\left(t_{i}\right)\right), i=1, \ldots, 204$, odpowiadaja przy przekształceniu (2) punkty $\left(x_{i}, y_{i}\right)$, które $\mathrm{w}$ przybliżeniu leżą na prostej (rys.1). W ten sposób dokonaliśmy wstępnej weryfikacji hipotezy, że badana cecha ma rozkład Weibulla. Metodą najmniejszych kwadratów otrzymujemy, że wspomniana prosta ma równanie $y=1,00378 \cdot x-9,54681$. Dla analizowanej próby punkty $\left(x_{i}, y_{i}\right), i=1, \ldots, 204$, oraz wyznaczoną prostą przedstawiono na rys. 1 .

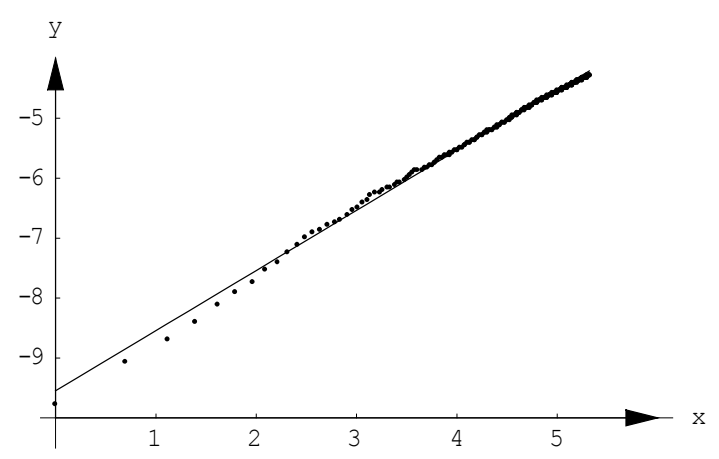

Rys.1. Punkty $\left(x_{i}, y_{i}\right)$ i prosta $y=1,00378 \cdot x-9,54681$ 
Zgodnie ze wzorem (3) otrzymujemy z pewnym przybliżeniem:

$\delta=1,00378, \quad \theta=\exp (9,54681)=13999,96348$

i następnie mamy funkcję $F(t)$, którą nazywamy dystrybuantą teoretyczną (hipotetyczna). Wartości $F_{E}\left(t_{i}\right)$ dystrybuanty empirycznej i wartości $F\left(t_{i}\right)$ dystrybuanty teoretycznej różnią się niewiele, o czym świadczą wykresy obu dystrybuant przedstawione dla $t=1, \ldots, 204$ na rys.2 (kolorem ciemniejszym zaznaczony jest wykres dystrybuanty teoretycznej).

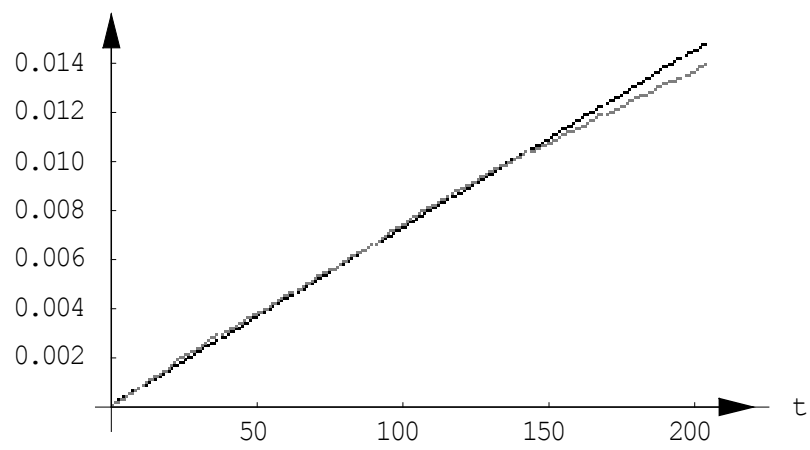

Rys.2. Wykresy funkcji $F(t), F_{E}(t)$ dla $t=1, \ldots, 204$

\subsection{Weryfikacja hipotezy o rozktadzie Weibulla}

Stawiamy hipotezę, że rozważana zmienna losowa $T$ ma rozkład Weibulla o parametrach $\delta=1,00378, \theta=13999,96348$. Postawiona hipoteze zweryfikujemy za pomocą testu Kołmogorowa [5] na poziomie istotności $\alpha=0,05$. Statystyką testową jest $D=\sup \left|F\left(t_{i}\right)-F_{E}\left(t_{i}\right)\right|$. Dla poziomu istotności $\alpha=0,05$ wartość krytyczna statystyki Kołmogorowa wynosi $d_{(0,05)}=1,354$. Skoro $\sqrt{204} \cdot D \approx 0,0124804<d_{(0,05)}$, więc analizowana próba nie przeczy na poziomie istotności $\alpha=0,05$ hipotezie, że badana cecha $T$ ma rozkład Weibulla.

\section{Rozdzial 3}

\subsection{Analiza wtaściwości badanej cechy o rozktadzie Weibulla}

Oszacowane na podstawie próby wartości parametrów $\delta, \theta$, które przedstawia wzór (4), pozwalają na zbudowanie i analizę pewnych funkcji teorii niezawodności $[1,3]$, np. funkcji gęstości $f(t)$, funkcji intensywności 
$\lambda(t)$, funkcji niezawodności $R(t)$. Funkcje te dla rozkładu Weibulla określone są dla $t>0$ następującymi wzorami:

$f(t)=\frac{\delta}{\theta} \cdot t^{\delta-1} \cdot \exp \left(-\frac{t^{\delta}}{\theta}\right), \quad \lambda(t)=\frac{\delta}{\theta} \cdot t^{\delta-1}, \quad R(t)=1-F(t)=\exp \left(-\frac{t^{\delta}}{\theta}\right)$, natomiast dla $t \leq 0$ jest $f(t)=0, \lambda(t)=0, R(t)=1$. Wykresy funkcji $\lambda(t)$, $R(t)$ dla obliczonych wartości $\delta, \theta$ przedstawione są na rys.3 (na osi pionowej dla wykresu funkcji $\lambda(t)$ przyjęto $\lambda(t) \cdot 10^{5}$ ).
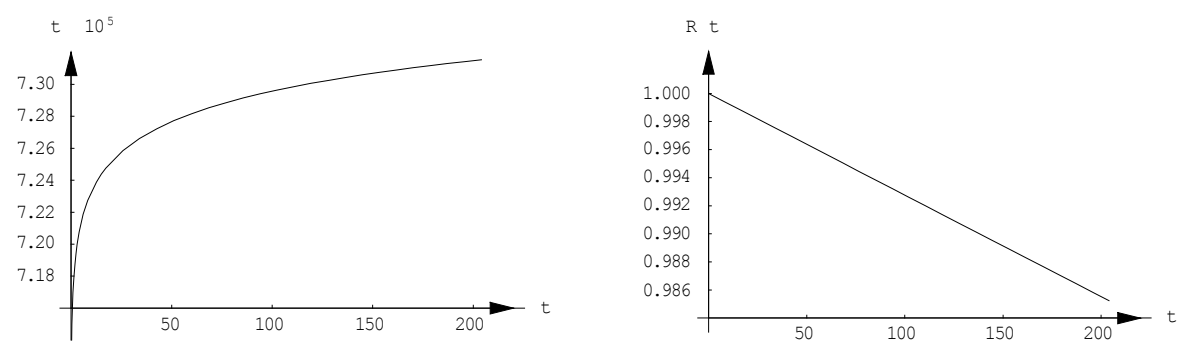

Rys.3. Wykresy funkcji $\lambda(t), R(t)$

\subsection{Interpretacja wyników analizy}

Analizowany system jest systemem pracującym awaryjnie. Pojawiają się $\mathrm{w}$ nim straty (w naszym przypadku ofiary śmiertelne). Zmienna losowa $T$ oznacza tu czas pracy z awarią, $F(t)$ oznacza prawdopodobieństwo, że do chwili $t$ pojawią się ofiary śmiertelne, natomiast $R(t)$ oznacza prawdopodobieństwo, że po chwili $t$ pojawią się ofiary śmiertelne. Funkcja $R(t)$ jest malejąca, co $\mathrm{w}$ naszym przypadku oznacza, że prawdopodobieństwo pojawienia się ofiary śmiertelnej po chwili $t$ maleje. Jest to sytuacja, której $\mathrm{z}$ punktu widzenia Krajowego Programu Bezpieczeństwa Ruchu Drogowego GAMBIT 2005 oczekujemy.

Dynamika spadku niezawodności awarii systemu określana jest przez funkcję intensywności $\lambda(t)$. Można zatem przyjać, że funkcja $\lambda(t)$ jest tu funkcją intensywności braku strat. Dla oszacowanych parametrów $\delta, \theta$ funkcja ta jest rosnąca, co oznacza, że brak strat rośnie, a to de facto znaczy, że straty maleją (więcej uczestników ruchu drogowego nie staje się ofiarami śmiertelnymi wypadków drogowych). Jest to sytuacja przez nas pożądana. Pozostaje jednak pytanie, czy dynamika spadku tych strat jest satysfakcjonująca? 


\section{Wnioski}

Zmienna losowa $T$ ma rozkład Weibulla dla różnych wartości współczynnika $\gamma$.

Zaprezentowana metoda hipotetycznie pozwala wykorzystywać inne sposoby modelowania wielkości ekspozycji na ryzyko w systemie transportu drogowego, np. poprzez wykorzystanie informacji o liczbie przejechanych kilometrów (tzw. pojazdo-kilometry), liczbie pojazdów (nie tylko osobowych) lub liczbie mieszkańców.

Metodami teorii niezawodności można analizować wielkość strat w transporcie drogowym, przy czym poszczególne wielkości mają swoją interpretację.

Okazało się, że globalny trend poprawy bezpieczeństwa mierzony liczbą śmiertelnych ofiar wypadków drogowych jest pozytywny, to znaczy malejący. Wszystko wskazuje jednak na to, że dynamika spadku liczby ofiar śmiertelnych jest zbyt mała, by osiagnacé cel Krajowego Programu Bezpieczeństwa Ruchu Drogowego GAMBIT 2005, tzn. nie więcej niż 2800 ofiar śmiertelnych w roku 2013.

Przedstawiona metoda stwarza nowe możliwości analiz bezpieczeństwa w transporcie drogowym, chociażby w zakresie porównań międzynarodowych, analiz dynamiki osiagania celów i ich sposobów, badania związku ryzyka $\mathrm{w}$ ruchu drogowym $\mathrm{z}$ wielkością ekspozycji, ponadto metodę tę można wykorzystać do prognozowania oraz symulacji.

Dr MILEWSKA ANITA, adiunkt na Wydziale Fizyki Technicznej i Matematyki Stosowanej Politechniki Gdańskiej. Specjalizacja: metody matematyczne w technice, układy dynamiczne, nieklasyczny rachunek operatorów

Dr inż. ŻUKOWSKA JOANNA, adiunkt na Wydziale Inżynierii Lądowej i Środowiska Politechniki Gdańskiej. Specjalizacja: inżynieria ruchu drogowego, bezpieczeństwo ruchu drogowego, polityka transportowa 
